\title{
Amino-Functional Polybenzimidazole Blends with Enhanced Phosphoric Acid Mediated Proton Conductivity as Fuel Cell Electrolytes
}

Aili, David; Javakhishvili, Irakli; Han, Junyoung; Jankova Atanasova, Katja ; Pan, Chao; Hvilsted, Søren; Jensen, Jens Oluf; Bjerrum, Niels J.; Li, Qingfeng

Published in:

Macromolecular Chemistry and Physics

Link to article, DOI:

10.1002/macp.201600059

Publication date:

2016

Document Version

Peer reviewed version

Link back to DTU Orbit

Citation (APA):

Aili, D., Javakhishvili, I., Han, J., Jankova Atanasova, K., Pan, C., Hvilsted, S., Jensen, J. O., Bjerrum, N. J., \& Li, Q. (2016). Amino-Functional Polybenzimidazole Blends with Enhanced Phosphoric Acid Mediated Proton Conductivity as Fuel Cell Electrolytes. Macromolecular Chemistry and Physics, 217(10), 1161-1168. https://doi.org/10.1002/macp.201600059

\section{General rights}

Copyright and moral rights for the publications made accessible in the public portal are retained by the authors and/or other copyright owners and it is a condition of accessing publications that users recognise and abide by the legal requirements associated with these rights.

- Users may download and print one copy of any publication from the public portal for the purpose of private study or research.

- You may not further distribute the material or use it for any profit-making activity or commercial gain

- You may freely distribute the URL identifying the publication in the public portal 


\section{Amino-Functional Polybenzimidazole Blends with Enhanced Phosphoric Acid- Mediated Proton Conductivity as Fuel Cell Electrolytes ${ }^{\mathrm{a}}$}

David Aili,* Irakli Javakhishvili,* Junyoung Han, Katja Jankova, Chao Pan, Søren Hvilsted, Jens Oluf Jensen, Niels J. Bjerrum, Qingfeng Li

Dr. D Aili, * Dr. K. Jankova, Dr. J. Han, C. Pan, Prof. J. O. Jensen, Prof. N. J. Bjerrum, Prof. Q. Li

Department of Energy Conversion and Storage, Technical University of Denmark, Kemitorvet 207, DK-2800 Kgs. Lyngby, Denmark

E-mail: larda@dtu.dk

Dr. I. Javakhishvili, * Prof. S. Hvilsted

Danish Polymer Centre, Department of Chemical and Biochemical Engineering, Technical

University of Denmark, Søltofts Plads 227, DK-2800 Kgs. Lyngby, Denmark

E-mail: irj@kt.dtu.dk

* The corresponding authors contributed equally to this work.

A new amino-functional polybenzimidazole copolymer is synthesized by homogeneous solution condensation polymerization from a novel monomer, $N, N^{\prime}$-bis(2,4-diaminophenyl)-1,3diaminopropane. The copolymer readily dissolves in organic solvents and shows good film forming characteristics. To balance the phosphoric acid uptake and to obtain mechanically robust membranes, the amino-functional polybenzimidazole derivative is blended with high molecular weight poly[2,2'(m-phenylene)-5,5'-bisbenzimidazole] at different ratios. Due to the high acid uptake, the homogenous blend membranes shows enhanced proton conductivity at temperatures well above $100{ }^{\circ} \mathrm{C}$ as also confirmed by the fuel cell polarization data.

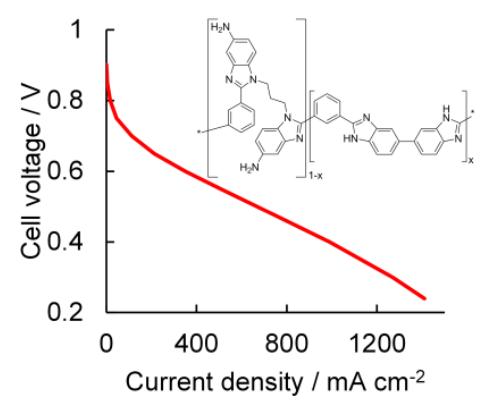

a Supporting Information is available online from the Wiley Online Library or from the author. 


\section{Introduction}

Fuel cells with electrolytes based on sulfonated polymers exhibit high power density, rapid response to load changes, and fast start-up time and are therefore of particular interest for mobile and automotive applications. ${ }^{[1]}$ However, such systems require advanced water management and fuel of very high purity due to the strong adsorption of, e.g. $\mathrm{CO}$, on the platinum electrocatalysts in the typical operating temperature range. ${ }^{[2]}$ The fuel impurity tolerance of the catalysts is, however, considerably improved at temperatures well above $100{ }^{\circ} \mathrm{C},{ }^{[3]}$ which facilitates direct feed of hydrogen-rich reformate to the anode ${ }^{[4]}$ and allows for less complex auxiliary units. ${ }^{[5]}$ This has triggered the development of new polymer electrolyte materials in which the proton transport is not watermediated. ${ }^{[6]}$

An early attempt was to replace water as the proton solvent in the conventional perfluorosulfonic acid membrane with phosphoric acid, ${ }^{[7]}$ which is a thermally stable acid with low vapor pressure exhibiting high proton conductivity at low water activities even at $200{ }^{\circ} \mathrm{C} .{ }^{[8]}$ The practical use of this electrolyte system in fuel cells was however limited, likely due to development of phosphoric acid imbalance during operation. ${ }^{[9]}$ A more successful approach was to immobilize the phosphoric acid in a polymer matrix based on poly[2,2'-( $m$-phenylene $)-5,5^{\prime}$-bisbenzimidazole $](m-$ $\mathrm{PBI}),{ }^{[10]}$ which resulted in a major breakthrough in the field of high temperature polymer electrolyte membranes.

Improved membrane preparation processes have been developed during the last two decades $^{[11]}$ and numerous new polybenzimidazole derivatives have been designed, synthesized and evaluated as potential base materials for the phosphoric acid doped membrane. These include e.g. polybenzimidazole sequence isomers, ${ }^{[12]}$ grafted polymers ${ }^{[13]}$ and structures containing ether, ${ }^{[14]}$ sulfone ${ }^{[15]}$ phenylindane,${ }^{[16]}$ naphtyl, ${ }^{[17]}$ triazole,${ }^{[18]}$, imidazole, ${ }^{[19]}$ hexafluoroisopropylidene, ${ }^{[20]}$ perfluorocyclobutyl $^{[21]}$ or other aliphatic perfluorinated ${ }^{[22]}$ linkages in the main chain. The proton 
conductivity of such electrolyte systems increases with increasing phosphoric acid content, but the acid also exerts a strong plasticizing effect resulting in dramatic softening and deterioration of the mechanical strength. Different covalent ${ }^{[15,20,23]}$ or ionic ${ }^{[24]}$ crosslinking concepts have therefore been studied for further improvements of chemical resistance and mechanical strength at high phosphoric acid contents.

Another critical issue in connection to fuel cell durability is to improve the acid retention of the membrane,${ }^{[25]}$ which seems most critical in the higher end of the operational temperature range. ${ }^{[26]}$ Functional polybenzimidazoles with additional basic moieties (e.g. pyridyl) in the main chain have been suggested as an effective approach to govern the interaction between the polymer and phosphoric acid, ${ }^{[27]}$ to enhance the acid uptake, ${ }^{[17,28]}$ and to prevent leaching during liquid water exposure. ${ }^{[29]}$ Alternatively, the additional basic moieties can be introduced by grafting functional side-chains, such as benzimidazole, ${ }^{[30]}$ phenoxyamine $^{[31]}$ or amino groups ${ }^{[32]}$ to the polymer backbone. The introduced amino groups can, in turn, be utilized for further crosslinking reactions ${ }^{[32]}$ or alkylation. ${ }^{[33]}$

This communication presents the preparation of a novel amino-functional polybenzimidazole copolymer, synthesized by condensation polymerization of 3,3'-diaminobenzidine (DAB), isophthalic acid (IPA) and a new hexamine monomer ( $N, N^{\prime}$-bis(2,4-diaminophenyl)-1,3diaminopropane). Structural peculiarities of the amino-functional polybenzimidazole copolymer were elucidated by spectroscopic tools and blend membranes with $m$-PBI were prepared at different ratios and characterized with respect to chemical and physicochemical characteristics and evaluated in fuel cell tests. 


\section{Experimental Section}

\subsection{Materials}

Palladium on activated charcoal (Aldrich, $10 \% \mathrm{Pd}$ basis), 1-fluoro-2,4-dinitrobenzene (Aldrich, $\geq 98 \%$ ), 1,3-diaminopropane (Aldrich, $\geq 99 \%$ ), hydrazine hydrate (Sigma-Aldrich, 50-60 \%), , 3,3’-diaminobenzidine (DAB; Glentham Life Sciences, $\geq 98.0 \%$ ), isophthalic acid (IPA; Sigma-Aldrich, 99 \%), polyphosphoric acid (PPA; Sigma-Aldrich, $115 \%$ ), chloroform (Sigma-Aldrich, $\geq 99.8 \%$ ), ethanol (Merck Millipore, $\geq 99.5 \%$ ), 2-propanol (Sigma-Aldrich, $\geq 99.5 \%$ ), hydrochloric acid (Fluka, $37 \%$ ), N,N-dimethylacetamide (DMAc; Sigma-Aldrich) and dimethyl sulfoxide- $d_{6}$ (DMSO- $d_{6}$, Aldrich, 99.9 atom $\%$ D) were used as received. Triethylamine (Riedel-de Haën, $99 \%$ ) was distilled before use. $m$-PBI with an inherent viscosity $\eta_{\text {inh }}$ of $0.83 \mathrm{dL} \mathrm{g} \mathrm{g}^{-1}\left(30.0^{\circ} \mathrm{C}, 0.051 \mathrm{~g} \mathrm{dL}^{-1}\right.$ in $\left.96 \% \mathrm{H}_{2} \mathrm{SO}_{4}\right)$ and $\bar{M}_{n}=49600$ $\mathrm{g} \mathrm{mol}^{-1}, \bar{M}_{w} / \bar{M}_{n}=3.87$ (from SEC) was supplied by Danish Power Systems ApS.

\subsection{Synthesis of amino-functional polybenzimidazole}

A $250 \mathrm{~mL}$ one-neck round bottom flask equipped with a magnetic stirring bar was charged with 1-fluoro-2,4-dinitrobenzene (20.1 g, $108.0 \mathrm{mmol})$, triethylamine $(30 \mathrm{~mL}, 215.2 \mathrm{mmol})$ and chloroform $(50 \mathrm{~mL})$. An addition funnel was attached and 1,3-diaminopropane (4.6 mL, $55.1 \mathrm{mmol})$ and chloroform $(20 \mathrm{~mL})$ were added dropwise to the reaction mixture at room temperature. The mixture was stirred under nitrogen atmosphere overnight, poured into 1 mol $\mathrm{L}^{-1}$ aqueous $\mathrm{HCl}(300 \mathrm{~mL})$ during stirring with a glass spatula. $N, N^{\prime}$-bis(2,4-dinitrophenyl)1,3-diaminopropane (BDNPDAP, 1) was isolated as dark yellow solid on a Büchner funnel, washed with deionized water several times and dried under vacuum. Yield: $>95 \%$. IR (neat): $3367,3086,2946,1611,1578,1520,1496,1459,1418,1325,1282,1249,1228,1148,1127$, 
$1099,1057,993,971,932,922,825,766,743,704,691,663,623,549,533,515,474,433$ $\mathrm{cm}^{-1}$.

1 (25.9 g, $63.7 \mathrm{mmol})$ and $\mathrm{Pd} / \mathrm{C}(2.5 \mathrm{~g})$ were subsequently suspended in ethanol (390 $\mathrm{mL}$ ) in a $1 \mathrm{~L}$ one-neck round bottom flask equipped with a magnetic stirring bar. Hydrazine hydrate $(56 \mathrm{~mL}, \sim 900-1100 \mathrm{mmol})$ was added dropwise during $30 \mathrm{~min}$ at $0{ }^{\circ} \mathrm{C}$. A reflux condenser was attached to the flask, and the reaction mixture was heated to $50{ }^{\circ} \mathrm{C}$ for one hour. The temperature was increased to $85^{\circ} \mathrm{C}$ and the mixture was stirred for $21.5 \mathrm{~h}$ resulting in a color change from yellow to dark purple/black. The crude reaction mixture was filtered to remove the catalyst. The filtrate was then concentrated under reduced pressure and added dropwise to a large excess of 2-propanol and kept at about $-20{ }^{\circ} \mathrm{C}$ overnight. $N, N^{\prime}$-bis $(2,4$ diaminophenyl)-1,3-diaminopropane (BDAPDAP, 2) was isolated as a dark purple precipitate by decantation and dried in a vacuum oven at $50^{\circ} \mathrm{C}$. Yield: $42 \%$. IR (neat): 3386, 3316, 3206, $3020,2927,2839,1618,1510,1471,1448,1379,1302,1229,1197,1147,1116,966,845$, 788, 654, 604, 580, 506, $444 \mathrm{~cm}^{-1} .{ }^{1} \mathrm{H}$ NMR (300 MHz, DMSO-d,$\left.\delta\right): 6.26\left(\mathrm{~d}, J_{\mathrm{o}}=8.2 \mathrm{~Hz}\right.$, $2 \mathrm{H},-\mathrm{Ar}), 5.94\left(\mathrm{~d}, J_{\mathrm{m}}=2.4 \mathrm{~Hz}, 2 \mathrm{H},-\mathrm{Ar}\right), 5.80\left(\mathrm{dd}, J_{\mathrm{m}}=2.4 \mathrm{~Hz}, J_{\mathrm{o}}=8.1 \mathrm{~Hz}, 2 \mathrm{H},-\mathrm{Ar}\right), 4.90-$ 3.25 (br, - $\mathrm{NH}_{2},-\mathrm{NH}-$ ), $2.97\left(\mathrm{t}, \mathrm{J}_{1,3}=6.8 \mathrm{~Hz}, 4 \mathrm{H},-\mathrm{NH}-\mathrm{CH}_{2}-\mathrm{CH}_{2}-\mathrm{CH}_{2}-\mathrm{NH}-\right), 1.81$ (m, 2H, NH- $\left.\mathrm{CH}_{2}-\mathrm{CH}_{2}-\mathrm{CH}_{2}-\mathrm{NH}-\right), 1.04$ (d, $J_{1,3}=6.1 \mathrm{~Hz}$, residual 2-propanol).

The polymerization was carried out according to the methodology reported elsewhere. ${ }^{[34]}$ In a typical experiment, dried DAB (3.61 g, $\left.16.85 \mathrm{mmol}\right), 2$ (1.20 g, $\left.4.21 \mathrm{mmol}\right)$ and IPA (3.50 g, $21.06 \mathrm{mmol})$ were charged to a round bottom flask containing $115 \%$ PPA (230 g). The mixture was heated to $150{ }^{\circ} \mathrm{C}$ and stirred using a mechanical agitator for $18 \mathrm{~h}$ under argon atmosphere. The temperature was subsequently increased to $220{ }^{\circ} \mathrm{C}$, and the mixture was stirred for additional $5 \mathrm{~h}$ to give a slightly viscous dark brown mixture. After cooling to room temperature the crude mixture was poured into demineralized water $(2 \mathrm{~L})$. 
The precipitate was extensively washed with demineralized water and kept in $1 \mathrm{~mol} \mathrm{~L}^{-1}$ aqueous $\mathrm{K}_{2} \mathrm{CO}_{3}$ at $70{ }^{\circ} \mathrm{C}$ for one day to remove residual phosphoric acid and subsequently washed with demineralized water until neutral $\mathrm{pH}$. The obtained PBI-NH , containing 14 mol\% of the amino-functional monomer (from NMR), was finally dried at $100{ }^{\circ} \mathrm{C}$ in a vacuum oven for two days. Yield: $~ 100 \%$. SEC: $\bar{M}_{n}=20400 \mathrm{~g} \mathrm{~mol}^{-1}, \bar{M}_{w} / \bar{M}_{n}=2.75$. IR (neat): $3612,3405,3150,3052,1626,1612,1590,1532,1494,1440,1404,1362,1282,1230,1169$, $1099,1017,985,953,902,849,795,760,687,658,603,500,456,421 \mathrm{~cm}^{-1}$.

\subsection{Membrane preparation}

$5 \mathrm{wt} \%$ solutions of PBI-NH$H_{2}$ and $m$-PBI in DMAc were prepared, and subsequently mixed at different ratios to give $0,3.5$, and $7.5 \mathrm{~mol} \%$ of the amino-functional unit. Membranes were cast on Petri dishes with a diameter of $11 \mathrm{~cm}$ by solvent evaporation during gradual heating from room temperature to

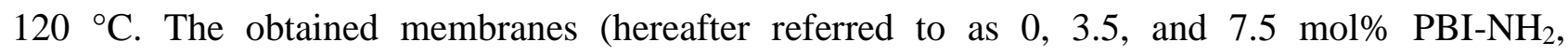
respectively) were delaminated from the glass substrates in demineralized water and further treated in demineralized water at $90{ }^{\circ} \mathrm{C}$ for $3 \mathrm{~h}$. For doping with phosphoric acid the membranes were equilibrated in $85 \mathrm{wt} \% \mathrm{H}_{3} \mathrm{PO}_{4}$ at room temperature for at least one week before use.

\subsection{Characterization}

Nuclear magnetic resonance (NMR) spectroscopy experiments were conducted on a Bruker Avance $300 \mathrm{MHz}$ spectrometer. Chemical shifts are reported in ppm relative to the solvent residual signal at $2.50 \mathrm{ppm}$ and the coupling constants are given in Hz. Attenuated total reflectance Fourier transform infrared (ATR FTIR) spectra in the range of 4000-350 $\mathrm{cm}^{-1}$ were acquired on a Nicolet iS50 ATR spectrometer with a diamond crystal from Thermo Scientific. Size exclusion chromatography (SEC) was carried out on a Shimadzu HPLC Instrument, equipped with two PolarSil columns (100 and 300 
Å) from Polymer Standards Service (PSS) and a Shimadzu refractive index (RI) detector. The system was controlled via the LabSolutions GPC software, which was also used for the data processing and calculations. DMAc containing $0.5 \mathrm{wt} \% \mathrm{LiCl}$ was used as the mobile phase with the flow rate of 1 $\mathrm{mL} \min ^{-1}$. The temperature of the columns was kept at $60{ }^{\circ} \mathrm{C}$. The number average molecular weight $\bar{M}_{n}$, weight average molecular weight $\bar{M}_{w}$, and the polydispersity index (PDI, $\bar{M}_{w} / \bar{M}_{n}$ ) were calculated based on a calibration curve obtained by using narrow molecular weight poly(methyl methacrylate) (PMMA) standards from PSS in the molecular weight range of 800-1600000 $\mathrm{g} \mathrm{mol}^{-1}$. Thermogravimetric analysis (TGA) was carried out on a using a Netzsch STA 409 PC at a heating rate of $10{ }^{\circ} \mathrm{C} \min ^{-1}$ in air.

The water uptake, as reported on the dry membrane basis, was determined gravimetrically by recording the weight loss after treating the membranes in demineralized water at $50{ }^{\circ} \mathrm{C}$ followed by drying at $110{ }^{\circ} \mathrm{C}$. Similarly, the acid uptake was calculated from the weight gain of membrane samples that had been dried for $3 \mathrm{~h}$ at $100{ }^{\circ} \mathrm{C}$ in vacuo before equilibration in $85 \mathrm{wt} \% \mathrm{H}_{3} \mathrm{PO}_{4}$ at room temperature for at least one week. The weight of the doped membranes was recorded after drying in vacuo at $80{ }^{\circ} \mathrm{C}$ for $1 \mathrm{~h}$. Similarly, the volume swelling was calculated on the dry undoped membrane basis from the volume increase after equilibration in $85 \mathrm{wt} \% \mathrm{H}_{3} \mathrm{PO}_{4}$ at room temperature for at least one week. The stress-strain curves and the conductivity data were recorded as described elsewhere. ${ }^{[23 a, 23 c]}$

The membrane electrode assemblies (MEAs) were prepared by sandwiching the phosphoric acid doped membranes between two pieces of gas diffusion electrodes (each $4 \mathrm{~cm}^{2}$ ) based on a nonwoven carbon substrate (Fruedenberg H2315 C2) with a platinum loading of $1.6 \mathrm{mg} \mathrm{cm}^{-2}(57 \%$ $\mathrm{Pt} / \mathrm{C})$ using $m$-PBI $\left(0.1 \mathrm{mg} \mathrm{cm}^{-2}\right)$ as binder. The MEAs were hot-pressed for $10 \mathrm{~min}$ at $180{ }^{\circ} \mathrm{C}$ under a pressure of 4.9 MPa. The MEAs were mounted in a cell-house made of stainless steel equipped with graphite flow fields and silver-plated current collectors. The anode and cathode were fed at ambient 
pressure with un-humidified hydrogen and air, respectively, at flow rates of 200 and $400 \mathrm{~mL} \mathrm{~min}^{-1}$, respectively.

\section{Results and Discussion}

\subsection{Synthesis of amino-functional monomer}

The novel monomer was synthesized through coupling of 2,4-dinitrophenyl moieties with 1,3diaminopropane, followed by subsequent mild and clean reduction of the nitro groups by hydrazine hydrate in the presence of the Pd catalyst (Scheme 1). The ATR-FTIR spectrum of 1 (Figure 1a) shows a characteristic band at $3367 \mathrm{~cm}^{-1}$ assigned to stretching vibration of the secondary aromatic amine N-H. Furthermore, absorption bands at 1611,1459 , and $1418 \mathrm{~cm}^{-1}$ originating from stretching vibrations of the aromatic $\mathrm{C}=\mathrm{C}$ bonds can be seen. The bands at 1578 and $1325 \mathrm{~cm}^{-1}$ are due to asymmetric and symmetric stretching vibrations of NO, while the bands at 1520 and $1496 \mathrm{~cm}^{-1} \mathrm{can}$ be assigned to bending vibrations of the secondary aromatic amine $\mathrm{N}-\mathrm{H}$ or the stretching vibrations of the aromatic $\mathrm{C}=\mathrm{C}$ bonds. After the reduction, bands originating from the stretching vibrations of NO are no longer observed. Instead, new bands at 3316 and $3206 \mathrm{~cm}^{-1}$ emerge in the spectrum of 2 , which are attributed to the asymmetric and symmetric stretching vibrations of the primary aromatic amine N-H confirming close to quantitative reduction of the nitro groups.

The signals at 5.80, 6.26, and $5.94 \mathrm{ppm}$ in the ${ }^{1} \mathrm{H}$ NMR spectrum of 2 (Figure 1b) can unequivocally be assigned to the corresponding protons of the benzene ring based on the splitting pattern and values of the coupling constants. While the broad signal at 3.25-4.90 ppm is attributed to the protons of primary and secondary amine functional groups, the triplet at $2.97 \mathrm{ppm}$ and the multiplet at $1.81 \mathrm{ppm}$ originate from the methylene groups of 1,3-propylidene fragment. A heteronuclear single quantum coherence (HSQC) experiment was conducted to identify the carbon 
atoms 1, 2, and 3 (Figure S1). They were found to appear at 103, 113, and $102 \mathrm{ppm}$, respectively, further confirming nearly full conversion of the nitro groups.

\subsection{Synthesis of amino-functional polybenzimidazole copolymer}

The novel polybenzimidazole random copolymer $\left(\mathrm{PBI}-\mathrm{NH}_{2}\right)$ was obtained by homogeneous solution condensation polymerization as depicted in Scheme 2, according to a similar procedure used for the synthesis of $m$-PBI. After isolation, extensive washing with water and dilute aqueous $\mathrm{K}_{2} \mathrm{CO}_{3}$, the molecular weight characteristics of PBI-NH 2 were investigated by SEC. The chromatogram (Figure 2a) verified formation of a polymer, though a small fraction of low molecular weight compounds was detected at high elution volumes. From a calibration curve obtained with a PMMA standard, $\bar{M}_{n}$ was found to be $20.400 \mathrm{~g} \mathrm{~mol}^{-1}$ and $\bar{M}_{w} / \bar{M}_{n}$ was 2.75 .

The FTIR spectrum of PBI-NH 2 displayed the main characteristic features of $m$-PBI, as shown in Figure 2b. The non-hydrogen-bonded N-H stretching vibration was detected at $3405 \mathrm{~cm}^{-1}$ and aromatic $\mathrm{C}-\mathrm{H}$ stretching vibration was identified at $3052 \mathrm{~cm}^{-1}$ whereas aromatic $\mathrm{C}=\mathrm{C}$ and $\mathrm{C}=\mathrm{N}$ stretching vibrations, ring vibration of the conjugated benzene and imidazole rings, and imidazole ring breathing manifested at 1612,1590 , and $1282 \mathrm{~cm}^{-1}$, respectively. ${ }^{[35]}$

The ${ }^{1} \mathrm{H}$ NMR spectrum of PBI-NH $\mathrm{N}_{2}$ is depicted in Figure 2c, where the ${ }^{1} \mathrm{H}$ NMR spectrum of $m$-PBI is shown for comparison. Broad resonance signals at 4.00-4.55 ppm and 2.05-2.40 ppm are assigned to $\mathrm{NCH}_{2} \mathrm{CH}_{2}$ and $\mathrm{NCH}_{2} \mathrm{CH}_{2}$ protons of 1,3-propylidene fragment, respectively. The assignment is substantiated by homonuclear correlated spectroscopy (COSY) experiment, which reveals that $\mathrm{H} 11$ and $\mathrm{H} 12$ belong to the same spin system (Figure S2). Furthermore, HSQC experiment reveals that the corresponding coupled carbons appear at $41 \mathrm{ppm}$ and $29 \mathrm{ppm}$ as expected (Figure S3). Peaks H8, H9, and $\mathrm{H} 10$ are ascribed to the protons in 2-(m-phenylene)-5aminobenzimidazole ring. The COSY experiment confirms that the protons $\mathrm{H} 8$ and $\mathrm{H} 9$ with the 
resonance signals at 6.48-6.77 and 7.11-7.44 ppm, respectively, couple, while the proton H10 is not included in that spin system and appears as a singlet at 6.77-6.97 ppm (Figure S2). In the HSQC experiment (Figure S3), the carbons coupled to the protons H8, H9, and $\mathrm{H} 10$ are detected at 113 ppm, $110 \mathrm{ppm}$, and $102 \mathrm{ppm}$, respectively, and thus corroborate the proposed structure. ${ }^{1} \mathrm{H}$ NMR experiment was employed to estimate the molar composition of $\mathrm{PBI}^{-\mathrm{NH}_{2}}$. Based on the comparison of the integrals of the resonance signals $\mathrm{H} 2-\mathrm{H} 7$ and $\mathrm{H} 10$, the content of the amino-functional unit in the copolymer was about $14 \%$ which is slightly lower than what could be expected from the stoichiometry during synthesis (see Scheme 2).

\subsection{Membrane preparation and characterization}

PBI-NH 2 showed good film-forming characteristics and thin membranes were cast by slow solvent evaporation from DMAc. The pristine $\mathrm{PBI}-\mathrm{NH}_{2}$ membrane was subsequently immersed in phosphoric acid. The phosphoric acid uptake appeared to be very high, resulting in excessive swelling and significant deterioration of the mechanical strength, which made further handling difficult. To reduce the acid uptake and to obtain mechanically robust membranes, $\mathrm{PBI}-\mathrm{NH}_{2}$ was therefore blended with high molecular weight $m$-PBI homopolymer. The two polymers were dissolved separately in DMAc and mixed at different ratios to form homogenous polymer blend solutions with $0,3.5$ and $7.5 \%$ of the amino-functional unit. Visually homogenous and transparent blend membranes were obtained after casting (Figure S4). The hydrophilicity of the blend membranes increased with increasing content of the amino-functional unit, as indicated by an increased water uptake from $19 \%$ for pristine $m$-PBI, corresponding to about 3 water molecules per polymer repeat unit, to $24 \%$ for the membrane with a PBI-NH 2 content of $7.5 \%$ (Table 1). The thermo-oxidative resistance of the resulting membranes was marginally reduced by the incorporation of the functional monomer, as indicated by a gradual decrease of the major onset of decomposition temperature from $557{ }^{\circ} \mathrm{C}$ for the pure $m$-PBI 
membrane to 542,537 and $528{ }^{\circ} \mathrm{C}$ for the membranes with $\mathrm{PBI}-\mathrm{NH}_{2}$ contents of $3.5,7.5$ and 14 mol\%, respectively. The corresponding thermogravimetric curves are shown in Figure S5, and the major onset of decomposition temperature was taken as the intersection of the tangents following the major slopes of the curve.

Doping with phosphoric acid was carried out and the acid uptakes and volume swellings were recorded, as summarized in Table 1 . The acid uptake of the $0 \% \mathrm{PBI}^{-\mathrm{NH}_{2}}$ (pure $m$-PBI) membrane corresponded to 11.6 phosphoric acid molecules per polymer repeat unit, which is consistent with previously reported data, also considering the volume swelling. ${ }^{[30 b]}$ The acid uptake and volume swelling increased gradually with increasing PBI-NH 2 content of the membrane and reached 505 and $354 \%$, respectively, for the membrane with $7.5 \% \mathrm{PBI}^{-\mathrm{NH}_{2}}$, apparently due to the additional basic sites in the structure as previously discussed. ${ }^{[29,32 \mathrm{a}]}$ During this process the primary amine groups are protonated to form positively charged ammonium moieties, further governing the interaction with the acid through columbic forces.

The mechanical behavior of the dry undoped membranes was similar regardless of the PBI$\mathrm{NH}_{2}$ content (Figure 3a). They showed elastic modulus of around $3 \mathrm{GPa}$, engineering tensile strength at break of $150 \mathrm{MPa}$ and a few percent elongation at break, which is typical for $m$-PBI. ${ }^{[23 \mathrm{a}]}$ Phosphoric acid is a strong plasticizer, causing dramatic softening when the $\mathrm{PBI}-\mathrm{NH}_{2}$, and thus the phosphoric acid content, increased (Figure 3b). For example, the elastic modulus of the phosphoric acid doped membrane with a PBI-NH 2 content of 0 mol\% (pure $m$-PBI) was $107 \mathrm{MPa}$ which can be compared with $25 \mathrm{MPa}$ for the membrane with a $\mathrm{PBI}-\mathrm{NH}_{2}$ content of $7.5 \mathrm{~mol} \%$ and considerably higher phosphoric acid content (see Table 1). Similarly, the engineering tensile strength was 11 and $5 \mathrm{MPa}$, respectively. In addition to facilitating the interaction with phosphoric acid, the functionality of the amino groups can be utilized for further crosslinking reactions to stabilize the structure at high phosphoric acid contents, as previously shown. ${ }^{[32]}$ 
The proton conductivity of the phosphoric acid doped membranes was recorded without humidification at $120-180{ }^{\circ} \mathrm{C}$, as summarized in Figure $4 \mathrm{a}$. The conductivity of the membrane with a PBI-NH 2 content of $0 \mathrm{~mol} \%$ (pure $m$-PBI) was about $64 \mathrm{mS} \mathrm{cm}^{-1}$ at $120{ }^{\circ} \mathrm{C}$ and reached $79 \mathrm{mS} \mathrm{cm}^{-1}$ at $160{ }^{\circ} \mathrm{C}$ in good agreement with previously reported data. ${ }^{[20 \mathrm{a}]}$ Increasing the temperature to $180{ }^{\circ} \mathrm{C}$ resulted in proton conductivity decay due to condensation of phosphoric acid and loss of water. ${ }^{[23 c \text {, }}$ ${ }^{36]}$ Because the conductivity correlates with the amount of phosphoric acid within the polymer matrix,${ }^{[37]}$ the conductivity of the membranes with $\mathrm{PBI}-\mathrm{NH}_{2}$ content of 3.5 and $7.5 \mathrm{~mol} \%$ was higher than that of the reference membrane and reached 96 and $117 \mathrm{mS} \mathrm{cm}^{-1}$, respectively, at $160{ }^{\circ} \mathrm{C}$.

Using the phosphoric acid doped membranes with $\mathrm{PBI}-\mathrm{NH}_{2}$ contents of $0,3.5$ and $7.5 \mathrm{~mol} \%$, preliminary fuel cell tests were conducted at $180{ }^{\circ} \mathrm{C}$ without external humidification (Figure $4 \mathrm{~b}$ ). The polarization resistance in the low current density region was practically identical for the cells based on the different membrane types, which can be expected for cells with identical electrodes. The losses in the higher current density region are predominantly of ohmic nature, where the internal resistance of the membrane is the main contributor. The in situ area specific resistance $R_{A S R}$ was obtained from non-linear regression by fitting the polarization data (excluding the mass transport region) to Equation 1, where $E$ is the cell voltage, $i$ is the current density, $a$ is a constant, and $b$ is the Tafel slope.

$E=a-b \log (i)-i R_{A S R}$

For the cells based on the membranes with $\mathrm{PBI}-\mathrm{NH}_{2}$ contents of $0,3.5$ and $7.5 \mathrm{~mol} \%$ the area specific resistance was found to be $0.38,0.28$ and $0.26 \Omega \mathrm{cm}^{2}$, respectively, corresponding to in situ proton conductivity of 26,36 and $38 \mathrm{mS} \mathrm{cm}^{-1}$, respectively. Because the fuel cell tests were carried out during a relatively short period of time, further durability studies are required to monitor the long-term effects 
of the introduction of the amino-functional unit and the aliphatic link in the main chain of the novel copolymer.

\section{Conclusions}

A novel amino-functional polybenzimidazole derivative was synthesized, showing high solubility in DMAc, good film forming characteristics and very high phosphoric acid uptake. To balance the high acid uptake on one hand and the mechanical robustness on the other, blend membranes with high molecular weight $m$-PBI homopolymer were prepared. This approach allowed for high acid uptakes and therefore enhanced proton conductivity at temperatures well above $100{ }^{\circ} \mathrm{C}$ and at low water activities, as also confirmed by the fuel cell polarization data.

\section{Supporting Information}

Supporting Information is available from the Wiley Online Library or from the author.

Acknowledgements: This work was financially supported by the Danish National Advanced Technology Foundation grant no. 017-2012-0 (High Technology Fuel Cell Manufacturing, HTFuma) and grant no. 55-2013-3.

Keywords: polybenzimidazole, copolymer, amino-functional, conductivity, fuel cell

\section{References}

[1] A. Kraytsberg, Y. Ein-Eli, Energy Fuels 2014, 28, 7303.

[2] H. F. Oetjen, V. M. Schmidt, U. Stimming, F. Trila, J. Electrochem. Soc. 1996, 143, 3838.

[3] G. Xiao, Q. F. Li, H. A. Hjuler, N. J. Bjerrum, J. Electrochem. Soc. 1995, 142, 2890. 
[4] a) C. Pan, R. He, Q. Li, J. O. Jensen, N. J. Bjerrum, H. A. Hjulmand, A. B. Jensen, J. Power Sources 2005, 145, 392; b) S. S. Araya, S. J. Andreasen, S. K. Kæer, Energies 2012, 5, 4251.

[5] Q. Li, R. H. He, J. O. Jensen, N. J. Bjerrum, Chem. Mater. 2003, 15, 4896.

[6] Q. Li, J. O. Jensen, R. F. Savinell, N. J. Bjerrum, Prog. Polym. Sci. 2009, 34, 449.

[7] R. Savinell, E. Yeager, D. Tryk, U. Landau, J. Wainright, D. Weng, K. Lux, M. Litt, C. Rogers, J. Electrochem. Soc. 1994, 141, L46.

[8] D.-T. Chin, H. Chang, J. Appl. Electrochem. 1989, 19, 95.

[9] D. Aili, R. F. Savinell, J. O. Jensen, L. N. Cleemann, N. J. Bjerrum, Q. Li, ChemElectroChem 2014, $1,1471$.

[10] J. S. Wainright, J. T. Wang, D. Weng, R. F. Savinell, M. Litt, J. Electrochem. Soc. 1995, 142, L121.

[11] a) H. -J. Kim, S. Y. Cho, S. J. An, Y. C. Eun, J. -Y. Kim, H. -K. Yoon, H. -J. Kweon, K. H. Yew, Macromol. Rapid Commun. 2004, 25, 894; b) H. -J. Kim, S. J. An, J. -Y. Kim, J. K. Moon, S. Y. Cho, Y. C. Eun, H. -K. Yoon, Y. Park, H. -J. Kweon, E. -M. Shin, Macromol. Rapid Commun. 2004, 25, 1410; c) L. X. Xiao, H. F. Zhang, E. Scanlon, L. S. Ramanathan, E. W. Choe, D. Rogers, T. Apple, B. C. Benicewicz, Chem. Mater. 2005, 17, 5328; d) A. Sannigrahi, D. Arunbabu, T. Jana, Macromol. Rapid Commun. 2006, 27, 1962; e) T. Steenberg, H. A. Hjuler, C. Terkelsen, M. T. R. Sanchez, L. N. Cleemann, F. C. Krebs, Energy Environ. Sci. 2012, 5, 6076.

[12] A. L. Gulledge, X. M. Chen, B. C. Benicewicz, J. Polym. Sci. Part A: Polym. Chem. 2014, 52, 619.

[13] P. R. Sukumar, W. C. Wu, D. Markova, O. Unsal, M. Klapper, K. Mullen, Macromol. Chem. Phys. 2007, 208, 2258.

[14] a) Y. S. Guan, H. T. Pu, D. C. Wan, Polym. Chem. 2011, 2, 1287; b) J. Li, X. J. Li, Y. Zhao, W. T. Lu, Z. G. Shao, B. L. Yi, ChemSusChem 2012, 5, 896. 
[15] J. Yang, D. Aili, Q. Li, L. N. Cleemann, J. O. Jensen, N. J. Bjerrum, R. He, ChemSusChem 2013, $6,275$.

[16] X. Li, X. Chen, B. C. Benicewicz, J. Power Sources 2013, 243, 796.

[17] A. Carollo, E. Quartarone, C. Tomasi, P. Mustarelli, F. Belotti, A. Magistris, F. Maestroni, M. Parachini, L. Garlaschelli, P. P. Righetti, J. Power Sources 2006, 160, 175.

[18] R. A. Potrekar, M. P. Kulkarni, R. A. Kulkarni, S. P. Vernekar, J. Polym. Sci. Part A: Polym. Chem. 2009, 47, 2289.

[19] Z. Liang, X. Jiang, H. Xu, D. Chen, J. Yin, Macromol. Chem. Phys. 2009, 210, 1632.

[20] a) J. Yang, Q. Li, L. N. Cleemann, J. O. Jensen, C. Pan, N. J. Bjerrum, R. He, Adv. Energy Mater. 2013, 3, 622; b) J. Yang, Y. Xu, P. Liu, L. Gao, Q. Che, R. He, Electrochim. Acta 2015, 160, 281.

[21] G. Q. Qian, D. W. Smith, B. C. Benicewicz, Polymer 2009, 50, 3911.

[22] H. Pu, L. Wang, H. Pan, D. Wan, J. Polym. Sci. Part A: Polym. Chem. 2010, 48, 2115.

[23] a) Q. Li, C. Pan, J. O. Jensen, P. Noyé, N. J. Bjerrum, Chem. Mater. 2007, 19, 350; b) M. Han, G. Zhang, Z. Liu, S. Wang, M. Li, J. Zhu, H. Li, Y. Zhang, C. M. Lew, H. Na, J. Mater. Chem. 2011, 21, 2187; c) D. Aili, L. N. Cleemann, Q. Li, J. O. Jensen, E. Christensen, N. J. Bjerrum, J. Mater. Chem. 2012, 22, 5444; d) H. Luo, H. Pu, Z. Chang, D. Wan, H. Pan, J. Mater. Chem. 2012, 22, 20696; e) N. Zhang, C. J. Zhao, W. J. Ma, S. Wang, B. L. Wang, G. Zhang, X. F. Li, H. Na, Polym. Chem. 2014, 5, 4939 .

[24] a) Q. Li, H. C. Rudbeck, A. Chromik, J. O. Jensen, C. Pan, T. Steenberg, M. Calverley, N. J. Bjerrum, J. Kerres, J. Membr. Sci. 2010, 347, 260; b) F. Mack, K. Aniol, C. Ellwein, J. Kerres, R. Zeis, J. Mater. Chem. A 2015, 3, 10864.

[25] Y. Oono, A. Sounai, M. Hori, J. Power Sources 2012, 210, 366.

[26] S. Yu, L. Xiao, B. C. Benicewicz, Fuel Cells 2008, 8, 165. 
[27] L. Xiao, H. Zhang, T. Jana, E. Scanlon, R. Chen, E. W. Choe, L. S. Ramanathan, S. Yu, B. C. Benicewicz, Fuel Cells 2005, 5, 287.

[28] a) J. Yang, Y. Xu, L. Zhou, Q. Che, R. He, Q. Li, J. Membr. Sci. 2013, 446, 318; b) S. Maity, T. Jana, Macromolecules 2013, 46, 6814.

[29] P. Mustarelli, E. Quartarone, S. Grandi, S. Angioni, A. Magistris, Solid State Ionics 2012, 225, 228.

[30] a) S.-K. Kim, T.-H. Kim, J.-W. Jung, J.-C. Lee, Polymer 2009, 50, 3495; b) J. Yang, D. Aili, Q.

Li, Y. Xu, P. Liu, Q. Che, J. O. Jensen, N. J. Bjerrum, R. He, Polym. Chem. 2013, 4, 4768.

[31] M. Kulkarni, R. Potrekar, R. A. Kulkarni, S. P. Vernekar, J. Polym. Sci. Part A: Polym. Chem. 2008, 46, 5776 .

[32] a) N. Xu, X. X. Guo, J. H. Fang, H. J. Xu, J. Yin, J. Polym. Sci. Part A: Polym. Chem. 2009, 47, 6992; b) S. Bhadra, N. H. Kim, J. H. Lee, J. Membr. Sci. 2010, 349, 304.

[33] Z. J. Xia, S. Yuan, G. P. Jiang, X. X. Guo, J. H. Fang, L. L. Liu, J. L. Qiao, J. Yin, J. Membr. Sci. 2012, 390, 152.

[34] a) J. Lee, J. Jung, J. Y. Han, H. J. Kim, J. H. Jang, H. J. Lee, E. A. Cho, D. Henkensmeier, J. Y. Kim, S. J. Yoo, S. A. Hong, S. Y. Nam, Macromol. Res. 2014, 22, 1214; b) S. H. Choi, D. H. Kim, D. Y. Kim, J. Y. Han, C. W. Yoon, H. C. Ham, J. H. Kim, H. J. Kim, S. W. Nam, T. H. Lim, J. Han, J. Appl. Polym. Sci. 2015, 132.

[35] P. Musto, F. E. Karasz, W. J. MacKnight, Polymer 1993, 34, 2934.

[36] A. Schechter, R. F. Savinell, Solid State Ionics 2002, 147, 181.

[37] D. Aili, J. O. Jensen, Q. Li, Polybenzimidazole Membranes by Post Acid Doping, in High Temperature Polymer Electrolyte Membrane Fuel Cells, (Eds. Q. Li, D. Aili, H. A. Hjuler, J. O. Jensen), Springer, New York, USA 2016, pp. 195-215. 



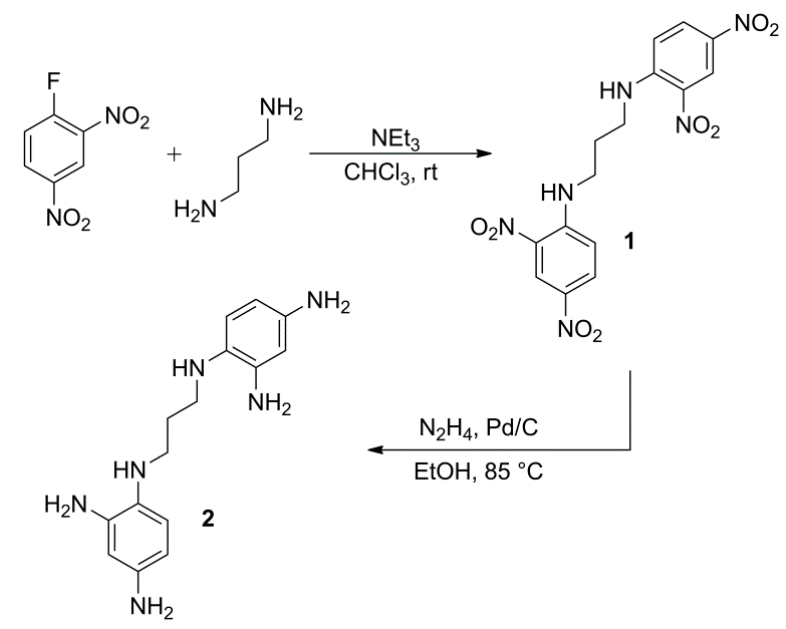

Scheme 1. Synthetic route for the preparation of the novel monomer.

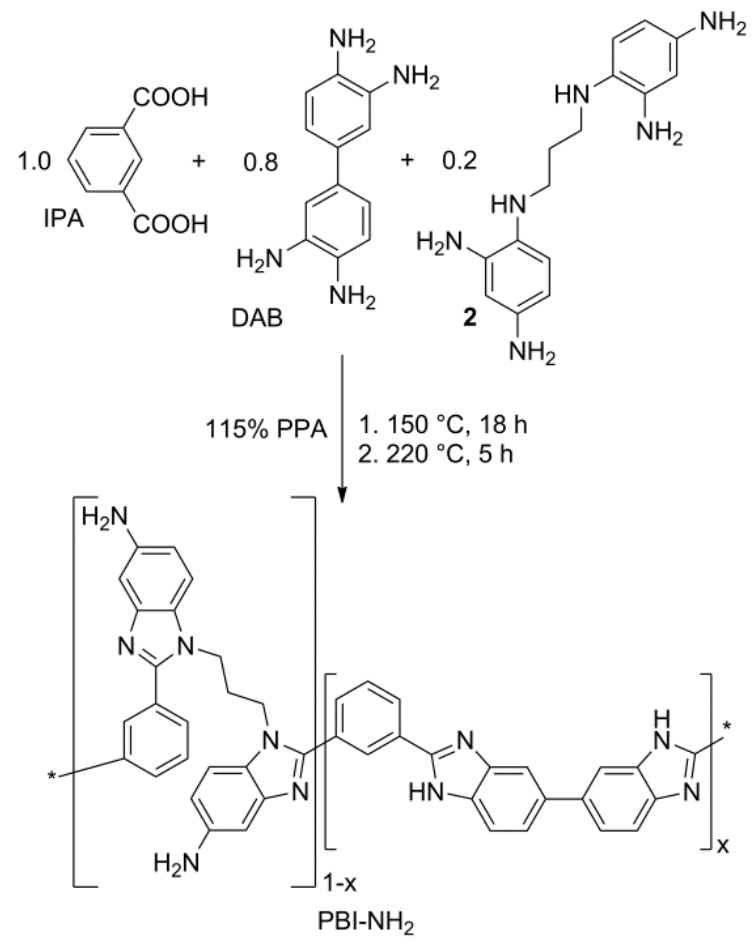

Scheme 2. Polycondensation of IPA, DAB, and 2 to give $\mathrm{PBI}_{-\mathrm{NH}_{2} .}$ 
a)

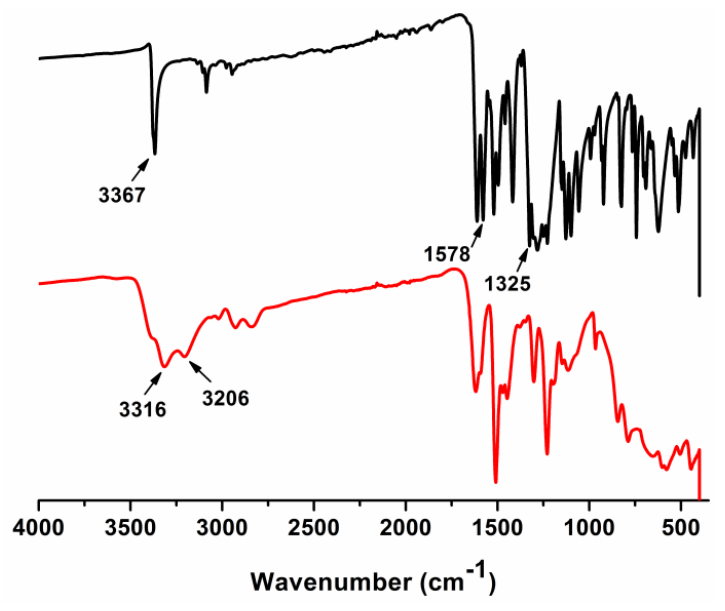

b)

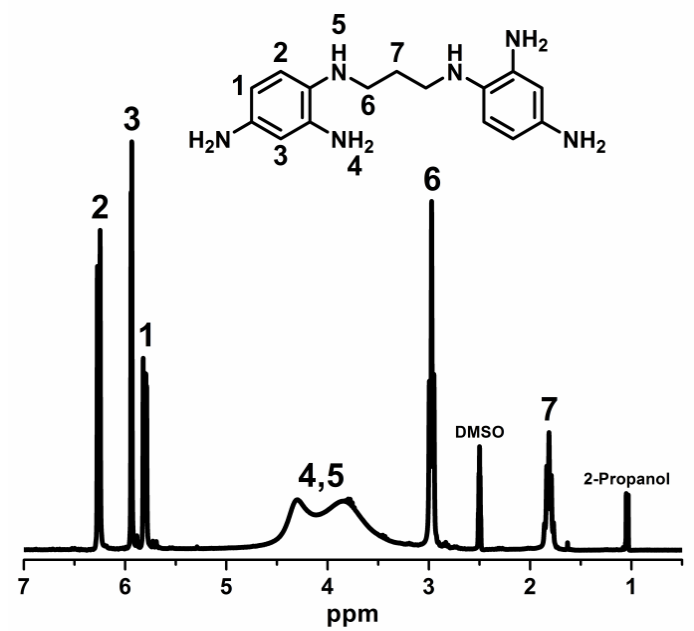

Figure 1. a) ATR FTIR spectra of $\mathbf{1}$ (top) and $\mathbf{2}$ (bottom); b) ${ }^{1} \mathrm{H}$ NMR spectrum of 2. 
a)

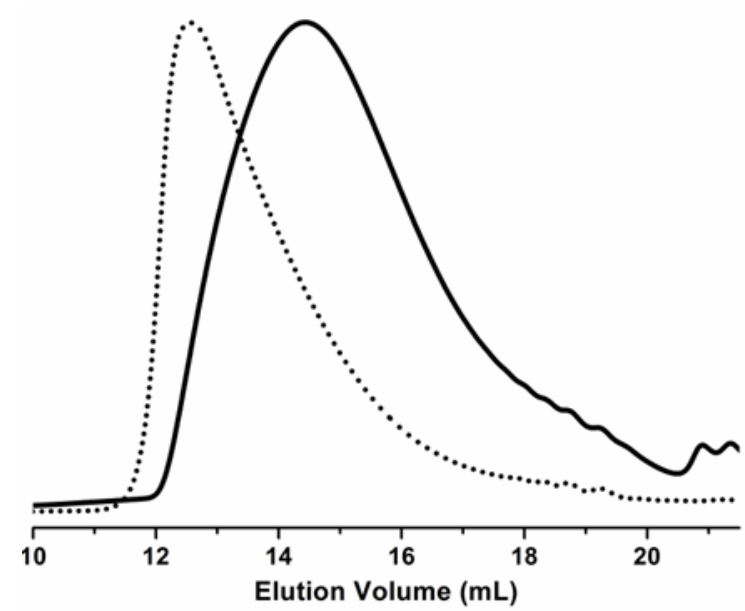

b)
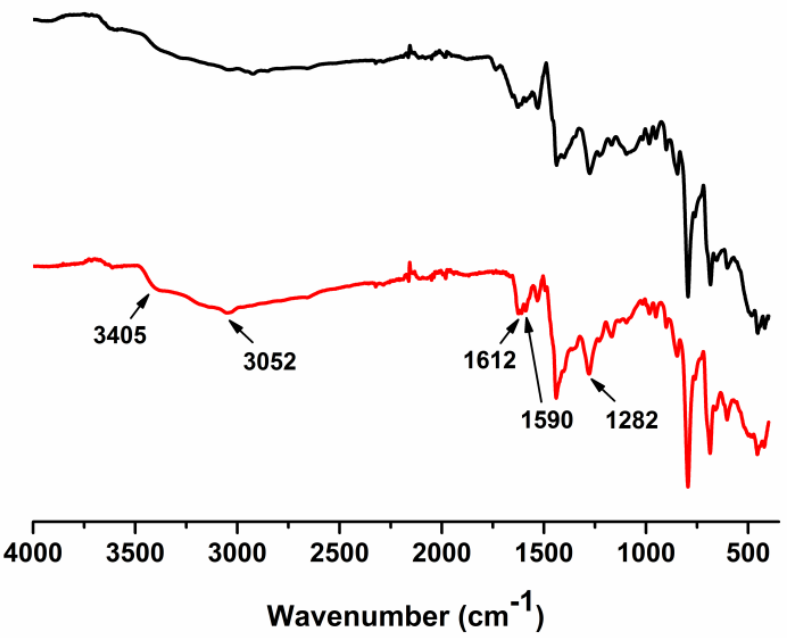

c)

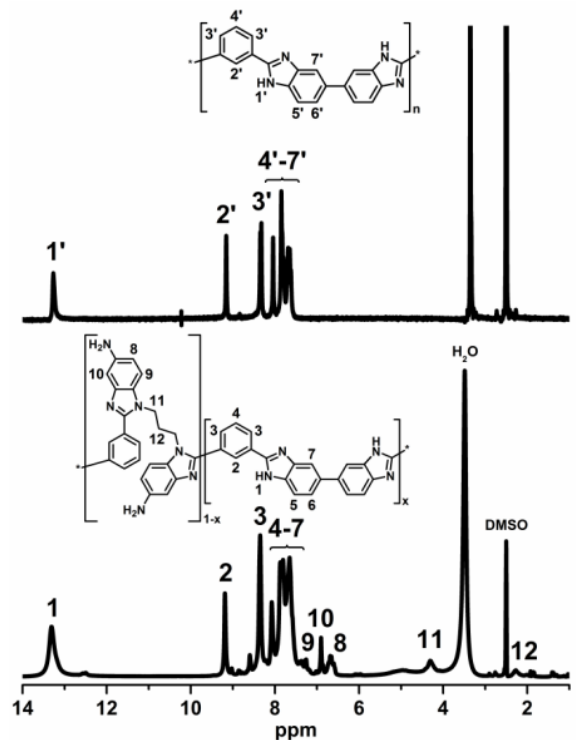

Figure 2. a) Overlay of SEC traces of PBI-NH 2 (solid) and $m$-PBI (dotted); b) ATR-FTIR spectra of $m$-PBI (top) and $\mathrm{PBI}-\mathrm{NH}_{2}$ (bottom); c) ${ }^{1} \mathrm{H}$ NMR spectra and corresponding peak assignments of $m$ $\mathrm{PBI}$ (top) and PBI-NH 2 (bottom). 

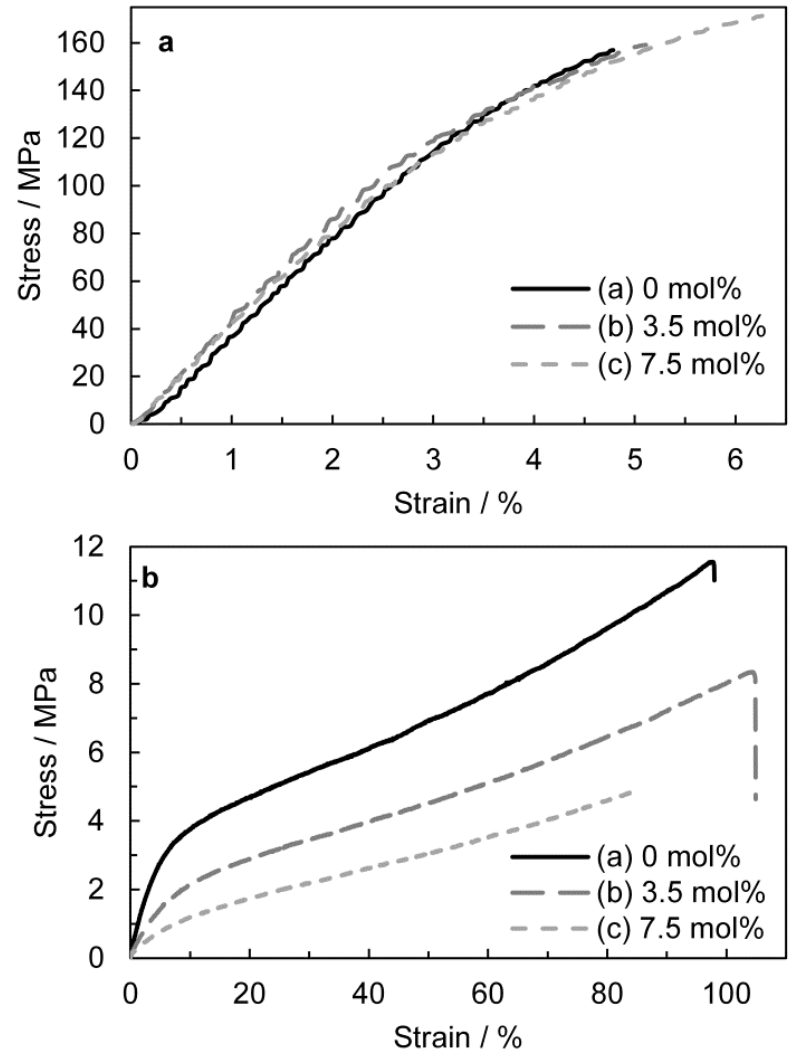

Figure 3. Representative stress-strain curves for the dry (a) and phosphoric acid doped (b) membranes with PBI- $\mathrm{NH}_{2}$ contents of $0,3.5$ and $7.5 \mathrm{~mol} \%$.

a)

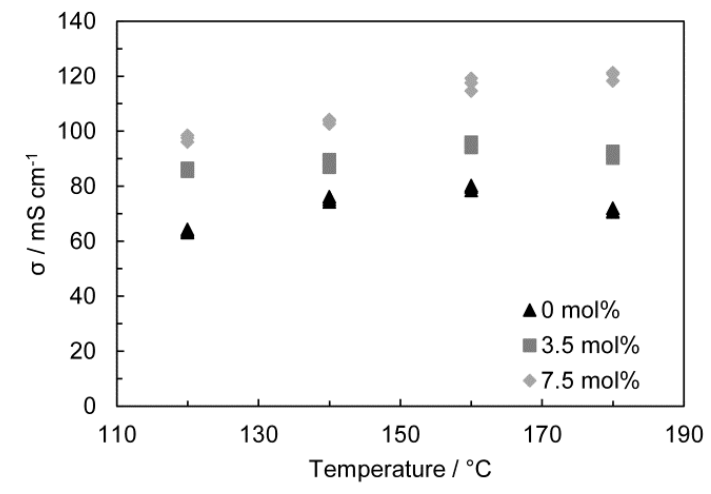

b)

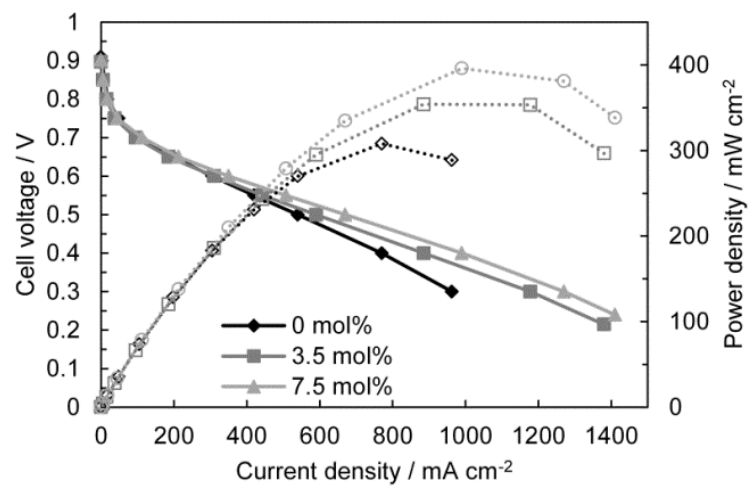

Figure 4. a) Proton conductivity data for the membranes with $\mathrm{PBI}_{-\mathrm{NH}_{2}}$ contents of $0,3.5$ and 7.5 mol\% at $120-180{ }^{\circ} \mathrm{C}$ under un-humidified air; b) Fuel cell polarization curves (solid symbols) and corresponding power densities (open symbols) at $180{ }^{\circ} \mathrm{C}$ for membrane electrode assemblies based on the membranes with PBI- $\mathrm{NH}_{2}$ contents of $0,3.5$ and $7.5 \mathrm{~mol} \%$. 
Table 1. Acid uptake and volume swelling for the membranes with $\mathrm{PBI}-\mathrm{NH}_{2}$ contents of $0,3.5$ and $7.5 \mathrm{~mol} \%$.

\begin{tabular}{lllllll}
\hline $\begin{array}{l}\text { PBI-NH } \\
\text { content } \\
{[\mathbf{m o l} \%]}\end{array}$ & $\begin{array}{l}\text { Water } \\
\text { uptake } \\
{[\mathbf{w t} \%]}\end{array}$ & $\begin{array}{l}\text { Acid } \\
\text { uptake } \\
{[\mathbf{w t} \%]}\end{array}$ & $\begin{array}{l}\mathbf{H}_{3} \mathbf{P O}_{4} \text { per } \\
\text { polymer } \\
\text { repeat unit }\end{array}$ & $\begin{array}{l}\text { Volume } \\
\text { swelling } \\
{[\text { vol\%] }}\end{array}$ & $\begin{array}{l}\text { Engineering } \\
\text { tensile } \\
\text { strenght } \\
{[\mathbf{M P a}]}\end{array}$ & $\begin{array}{l}\text { Elastic } \\
\text { modulus } \\
{[\mathbf{M P a}]}\end{array}$ \\
\hline 0 & 19 & 369 & 11.6 & 272 & 11 & 107 \\
3.5 & 23 & 435 & $13.8^{\text {a) }}$ & 315 & 8 & 58 \\
7.5 & 24 & 505 & $16.2^{\text {a) }}$ & 354 & 5 & 25 \\
\hline
\end{tabular}

a) Calculated based on the average repeat unit molecular weight. 
A novel amino-functional polybenzimidazole copolymer is synthesized from isophthalic acid, 3,3'diaminobenzidine and new a multifunctional monomer, obtained by coupling of 2,4 dinitrophenyl with 1,3-diaminopropane followed by mild and clean reduction with hydrazine hydrate. Blends of the new polymer with conventional polybenzimidazole afford mechanically robust membranes showing enhanced phosphoric acid uptake, increased proton conductivity and improved fuel cell performance.

D. Aili,* I. Javakhishvili,* J. Han, K. Jankova, C. Pan, S. Hvilsted, J. O. Jensen, N. J. Bjerrum, Q. $\mathrm{Li}$

Amino-Functional Polybenzimidazole Blends with Enhanced Phosphoric Acid-Mediated Proton Conductivity as Fuel Cell Electrolytes

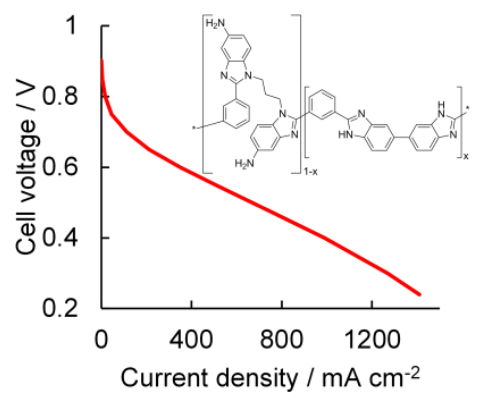




\section{Supporting Information}

for Macromol. Chem. Phys., DOI: 10.1002/marc.2013\#\#\#\#\#

Amino-Functional Polybenzimidazole Blends with Enhanced Phosphoric Acid-Mediated Proton Conductivity as Fuel Cell Electrolytes

David Aili, ' Irakli Javakhishvili, Junyoung Han, Katja Jankova, Chao Pan, Søren Hvilsted, Jens Oluf Jensen, Niels J. Bjerrum, Qingfeng Li

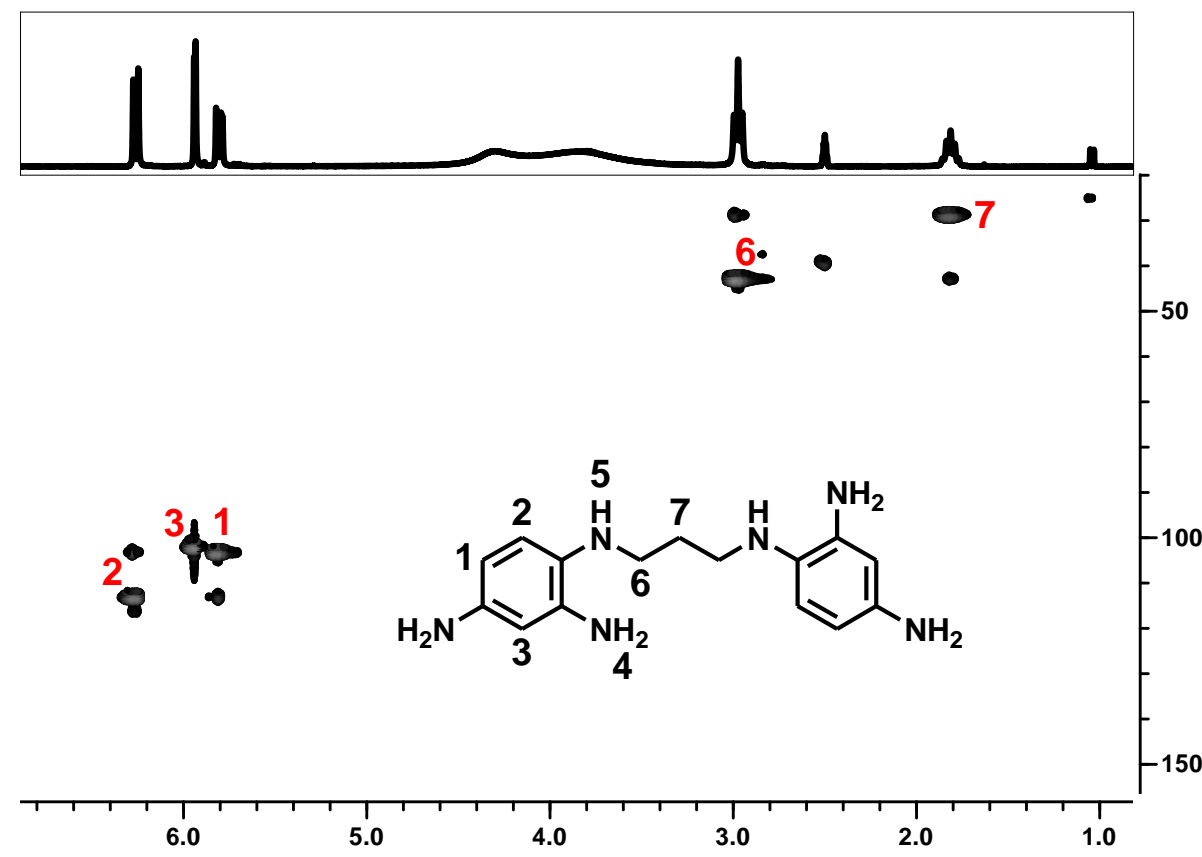

Figure S1. HSQC spectrum of ( $N, N^{\prime}$-bis(2,4-diaminophenyl)-1,3-diaminopropane) (2) acquired in DMSO- $d_{6}$. 


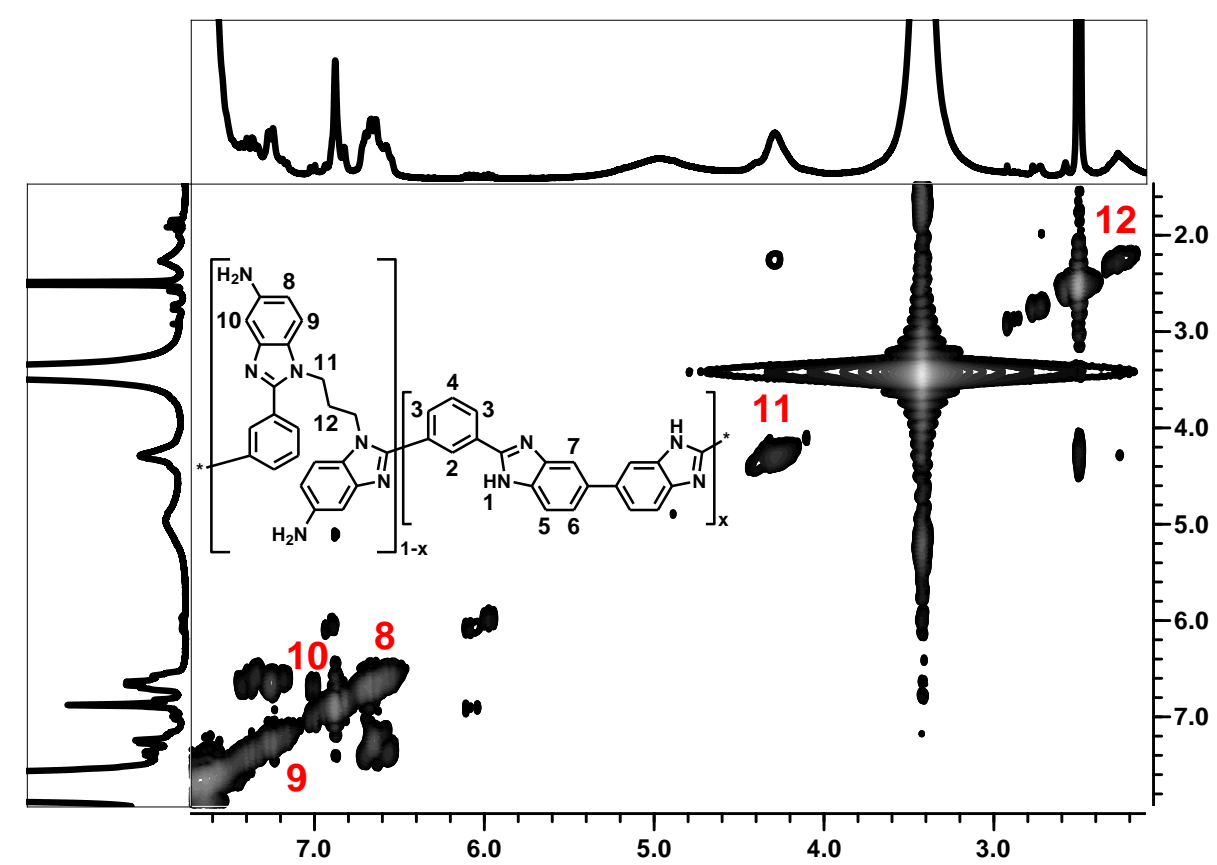

Figure $S 2$. COSY spectrum of PBI-NH 2 acquired in DMSO- $d_{6}$.

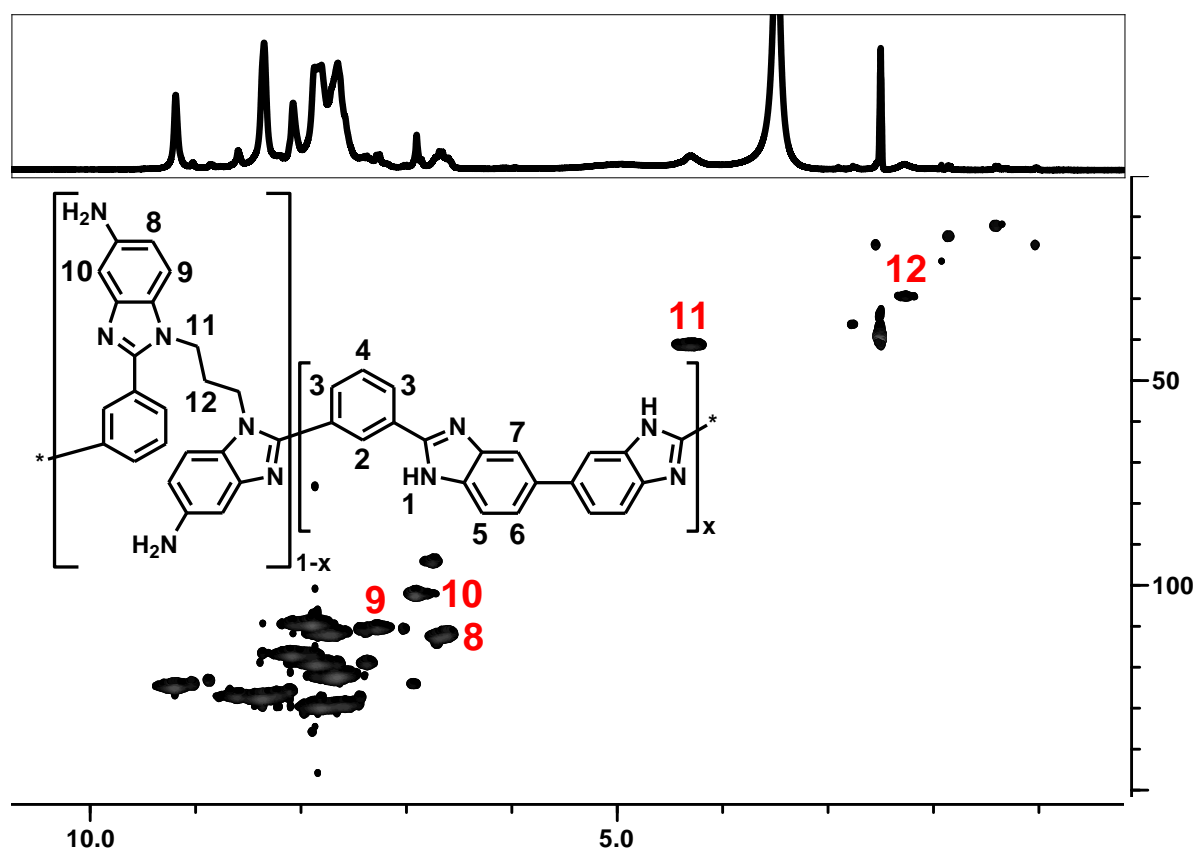

Figure S3. HSQC spectrum of PBI-NH $\mathrm{N}_{2}$ acquired in DMSO- $d_{6}$. 


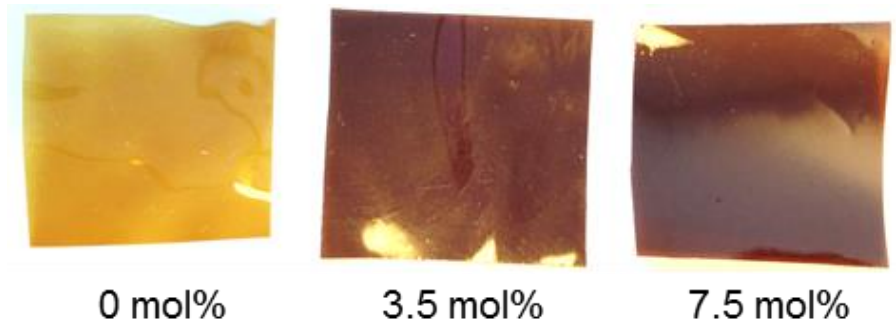

Figure S4. Photographs of the membranes with PBI-NH 2 contents of $0,3.5$ and $7.5 \mathrm{~mol} \%$.

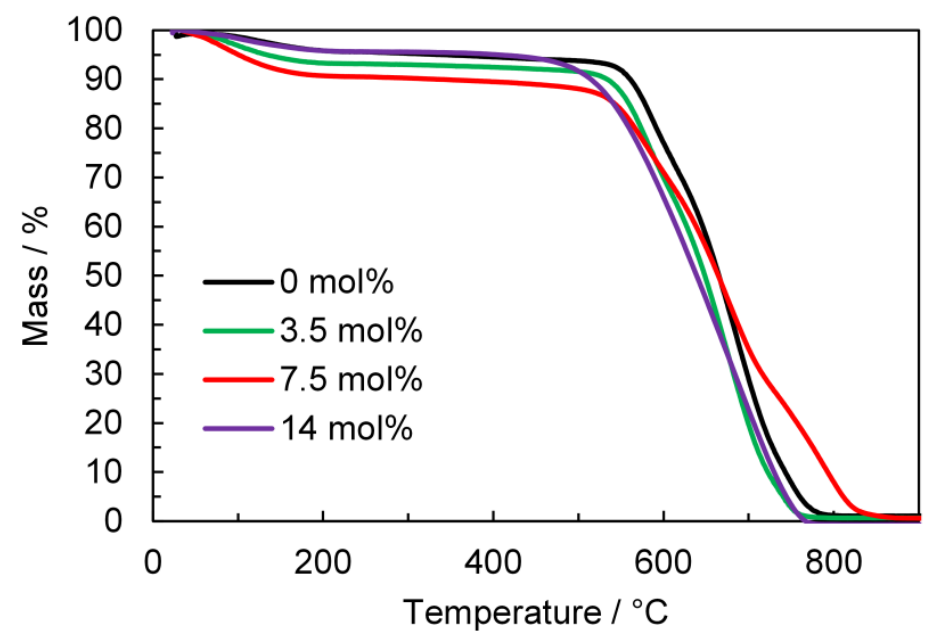

Figure S5. Thermogravimetric curves for the membranes with $\mathrm{PBI}_{-} \mathrm{NH}_{2}$ contents of $0,3.5$ and 7.5 mol\%. 